\title{
SOIL MANAGEMENT AND NITROGEN FERTILIZATION FOR SPRINKLER-IRRIGATED UPLAND RICE CULTIVARS
}

\author{
Orivaldo Arf ${ }^{1,4 *}$; Ricardo Antonio Ferreira Rodrigues ${ }^{2}$; Carlos Alexandre Costa Cruscioli3; Marco \\ Eustáquio de Sá1; Salatiér Buzetti ${ }^{2}$ \\ ${ }^{I}$ UNESP/FEIS - Depto. Fitotecnia, Tecnologia de Alimentos e Sócio-Economia, C.P. 31 - 15385-000 - Ilha Solteira, SP - Brasil. \\ ${ }^{2}$ UNESP/FEIS - Depto. Fitossanidade, Engenharia Rural e Solos. \\ ${ }^{3}$ UNESP/FCA - Depto. Produção Vegetal, C.P. 237 - 18603-970 - Botucatu,SP - Brasil. \\ ${ }^{4} \mathrm{CNPq}$ scholar. \\ *Corresponding author <arf@agr.feis.unesp.br >
}

\begin{abstract}
The use of sprinkler irrigation for rice (Oryza sativa L.) crop is a relatively recent practice in Brazil. Therefore, crop soil and fertilization management are still not very well defined. Another problem is the inexistence of specific cultivars adapted to this cropping system. This study aimed to evaluate sprinklerirrigated upland rice cultivars under different soil management practices and nitrogen sidedressing rates in relation to yield and grain quality. A randomized block design was used, arranged as a 3 x $3 \times 5$ factorial scheme, totaling 45 treatments consisting of the combination of three rice cultivars (Primavera, Confiança and Maravilha), three soil management systems (disk harrow + levelling harrow, moldboard plow + levelling harrow and no-till) and five nitrogen rates, applied as sidedressing $\left(0,25,50,75\right.$ and $\left.100 \mathrm{~kg} \mathrm{ha}^{-1}\right)$, with four replicates. The experiment was set up during the 1999/2000 and 2000/2001 cropping seasons, in Selvíria, MS, Brazil, on a Typic Haplustox of clayey texture. Cultivars Primavera and Maravilha presented higher grain yield than Confiança; on the other hand the latter showed higher milled and head rice yields during seed processing. Soil tillage with the moldboard plow and no-till interfered positively in the agronomic and productive characteristics of the crop. In relation to milled rice yield, tilling with the levelling disk + moldboard plow showed better results in relation to no-till. Nitrogen sidedressing did not interfere with the agronomic and productive characteristcs as well as with the milled rice yield of all cultivars.
\end{abstract}

Key words: Oryza sativa L, yield components, moldboard plow, harrow, no-till

\section{MANEJO DO SOLO E ADUBAÇÃO NITROGENADA PARA CULTIVARES DE ARROZ DE TERRAS ALTAS IRRIGADOS POR ASPERSÃO}

RESUMO: O uso da irrigação por aspersão para a cultura do arroz (Oryza sativa L.) é prática relativamente recente no Brasil. Desta forma, o manejo do solo e da adubação ainda não estão bem definidos para esta prática agrícola. Um outro problema é a falta de cultivares específicos para essa modalidade de cultivo. Desse modo, propôs-se o estudo com o objetivo de avaliar o comportamento de cultivares de arroz de terras altas irrigados por aspersão em função do manejo do solo e da adubação nitrogenada em cobertura quanto à produção e qualidade de grãos. $\mathrm{O}$ delineamento experimental utilizado foi em blocos ao acaso disposto em um esquema fatorial 3 x 3 x 5 , totalizando 45 tratamentos constituídos pela combinação de três cultivares de arroz (Primavera, Confiança e Maravilha), três modalidades de manejo do solo (grade aradora + grade niveladora, arado de aiveca + grade niveladora e plantio direto) e cinco doses de nitrogênio em cobertura $\left(0,25,50,75\right.$ e $\left.100 \mathrm{~kg} \mathrm{ha}^{-1}\right)$, com quatro repetições. O experimento foi conduzido durante os anos agrícolas de 1999/00 e 2000/01, no município de Selvíria, MS, num Latossolo Vermelho álico, textura argilosa. Os cultivares Primavera e Maravilha apresentaram maior produtividade de grãos em relação ao Confiança, por outro lado, este apresentou maior rendimento de benefício e de inteiros no beneficiamento. O preparo do solo com arado de aiveca e o plantio direto interferiram positivamente nas características agronômicas e produtivas da cultura. Já no rendimento de engenho, o preparo do solo com grade e arado de aiveca apresentaram melhor resultado em relação ao plantio direto. A adubação nitrogenada em cobertura não interferiu nas características agronômicas e produtivas e no rendimento de engenho dos cultivares testados.

Palavras - chave: Oryza sativa L., componentes do rendimento, arado de aiveca, grade, plantio direto

\section{INTRODUCTION}

Inadequate water and nitrogen management for sprinkler-irrigated rice has caused severe plant lodging, depending on the grown cultivar. Soil tillage when properly conducted, can improve soil water storage and save irrigation water. In recent years no-till is an ever growing practice. Recently, highly productive cultivars have 
been introduced, with long and thin type grain that has a high commercial value, and an evaluation of their behavior under different soil tillage and fertilization management systems is needed.

When sprinkler irrigation is used, it is recommended to phosphate fertilization to be increased by about $50 \%$, and potassium by $30 \%$ (Stone \& Pereira, 1994). However, inadequate irrigation and nitrogen management practices have caused a strong tendency to promote lodging of upland cultivars, since most of them are relatively tall in size and stalks, and not very resistant to lodging.

Nitrogen fertilization increases the number of stalks and panicles per unit area (Diniz, 1975; Campello Jr., 1985), the number of spikelets (Fornasieri Filho \& Fornasieri, 1993), fertility and grain mass (Aquino, 1984). In addition, nitrogen is the nutrient which more intensely affects plant height, causing lodging (Diniz, 1975; Campello Jr., 1985; Arf, 1993). High levels of $\mathrm{N}$ in traditional-type upland cultivars can cause partial or total lodging of rice plants, especially when the sprinkler-irrigated system is adopted. However, modern type cultivars under the same conditions of soils and cultural practices do not present lodging, even when fertilized with high nitrogen levels (Diniz et al., 1976). This occurs because of plant architecture, which responds to the utilization of high rates of $\mathrm{N}$ by increasing productivity without lodging, especially because are endowed with a more efficient system for photosynthate translocation to the grains in the vegetative stage (Crusciol, 1998).

Studying the behavior of the cultivars Rio Paranaíba, Guarani and Araguaia submitted to different nitrogen rates applied as sidedressing $(0,30,60$ and 90 $\mathrm{kg} \mathrm{ha}^{-1}$ ) (Arf et al., 1996), observed that nitrogen did not influence the agronomic characteristcs and the milled rice yield components. On the other hand, Stone et al. (1999) studied the most suitable rate of $\mathrm{N}$ for sprinkler-irrigated modern-type cultivars, cropped with $0.20 \mathrm{~m}$ spacing between rows upland rice during three years, and concluded that rice response to nitrogen fertilization is a result of the fertilizer effect on the numbers of panicles per $\mathrm{m}^{2}$ and of grains per panicle, and that the maximum economic $\mathrm{N}$ rate for upland rice, sown in rows, is $87.3 \mathrm{~kg} \mathrm{ha}^{-1}$, considering a $6: 1$ price ratio between a $\mathrm{kg}$ of $\mathrm{N}$ and a $\mathrm{kg}$ of rice, as of June, 1997.

The objective of this study was to evaluate the behavior of different sprinkler-irrigated upland rice cultivars under different soil management practices and nitrogen sidedressing rates in regard to yield and grain quality.

\section{MATERIAL AND METHODS}

This research was carried out during the 1999/00 and 2000/01 cropping seasons, in Selvíria, MS, Brazil, $\left(51^{\circ} 22^{\prime} \mathrm{W} ; 20^{\circ} 22^{\prime} \mathrm{S}\right.$, at altitude $\left.335 \mathrm{~m}\right)$. The soil is a clayey textured, Typic Haplustox. The mean annual precipitation is $1,370 \mathrm{~mm}$, with a mean annual temperature of $23.5^{\circ} \mathrm{C}$ and mean annual relative humidity between 70 and $80 \%$.

Soil samples were collected from the experimental area and submitted to chemical analysis according to the methodology proposed by Raij \& Quaggio (1983), yielding the following values: $\mathrm{OM}=21 \mathrm{~g} \mathrm{dm}^{-3} ; \mathrm{P}$ $($ resin $)=18 \mathrm{mg} \mathrm{dm}{ }^{-3} ; \mathrm{pH}\left(\mathrm{CaCl}_{2}\right)=5.0 ; \mathrm{K}, \mathrm{Ca}, \mathrm{Mg}$ and $\mathrm{H}+\mathrm{Al}=1.6 ; 22 ; 15$ and $34 \mathrm{mmol}_{\mathrm{c}} \mathrm{dm}^{-3}$, respectively, and $\mathrm{V}=53 \%$.

The soil water retention capacity was determined by using a suction unit, according to Grohmann (1960), operating in the range of $0.002 \mathrm{MPa}$ to $0.01 \mathrm{MPa}$, porous pressure plate apparatus as recommended by Richards \& Fireman (1943) in the range of $0.033 \mathrm{MPa}$ to $0.101 \mathrm{MPa}$, and the Richards (1947) membrane in the range of $0.101 \mathrm{MPa}$ to $1.520 \mathrm{MPa}$.

The experimental design consisted of random blocks organized as a $3 \times 3 \times 5$ factorial scheme totaling 45 treatments resulting from the combination of three upland rice cultivars (Confiança, Maravilha and Primavera), three soil management systems (moldboard plow + levelling harrow, disk harrow + levelling harrow, and notill) and five nitrogen sidedressing rates $(0,25,50,75$ and $100 \mathrm{~kg} \mathrm{ha}^{-1}$ ), with 4 replicates.

Soil tillage, depending on the treatment, was accomplished with a moldboard plow or a disk harrow and two harrowings to level the land, with the last operation performed just before sowing. A treatment was also adopted in which the soil was not revolved, i.e., no-till. The area assigned to no-till plots entered the system in 1997. The experiment was installed in an area where millet had been previously planted as a cover crop in the winter period for the production of mulch needed for the notill system. Millet was sown beginning September/1999 and September/2000, and conducted under irrigation until the first half of November.

The plots consisted of 7 rows, $6.0 \mathrm{~m}$ in length and spaced at $0.34 \mathrm{~m}$, totaling $14.28 \mathrm{~m}^{2}$. The usable area consisted of the 5 central rows, leaving out $0.50 \mathrm{~m}$ at the end of each row. A 6.0-m wide, empty space was left between plots.

Water was supplied by a fixed conventional sprinkler irrigation system with the sprinklers adjusted to provide a mean precipitation of $3.3 \mathrm{~mm}$ hour ${ }^{-1}$, allowing irrigation to be individualized per plot, since cultivars have different cycles. Precipitation was determined with a Ville de Paris pluviometer installed at the center of the experimental area.

Water replacement was performed when the accumulated maximum evapotranspiration $(\mathrm{ETm})$ reached values close to the preset values of the soil available water capacity ( $\mathrm{AWC}=10 \mathrm{~mm}$ ). A class tank was utilized to con- 
trol irrigation. The class A tank coefficient $(\mathrm{Kp})$ was the one proposed by Doorenbos \& Pruitt (1976), calculated based on the surrounding area, wind speed and relative humidity.

Three crop coefficients $(\mathrm{Kc})$ were used for water management, distributed across four periods comprised between the emergence and the harvest. During the vegetative stage the value 0.4 was utilized; for the reproductive stage two crop coefficients were used, one initial of 0.70 and a final of 1.00 , and for the maturation stage these values were inverted, that is, initial of 1.00 and final of 0.70 .

The basic chemical fertilization was calculated according to the soil chemical characteristics and taking into account recommendations by Raij et al. (1996) and Stone \& Pereira (1994). Two hundred and eighty (280) $\mathrm{kg} \mathrm{ha}^{-1}$ of the $4-30-10+0.3 \% \mathrm{Zn}$ were applied at sowing, and 20 days after the emergence of seedlings another $25 \mathrm{~kg} \mathrm{ha}^{-1} \mathrm{~K}_{2} \mathrm{O}$ were applied as sidedressing to supplement the necessary potassium rate as well as $\mathrm{N}$ rates.

Sowing was performed on November 16, 1999 and on November 24, 2000. This is the most indicated month for sowing sprinkler-irrigated rice in the region, since it is assumed to provide the highest productivities (Arf et al., 2000). Number of seeds was calculated to establish a population of 120 plants $\mathrm{m}^{-2}$. Seeds were treated with $525 \mathrm{~g}$ a.i. of thiodicarb $100 \mathrm{~kg}^{-1}$ seeds, to control termites and the cornstalk borer.

Weed control was accomplished with herbicides applied by tractor sprayer. In the case of no-till, soil mulch desiccation was achieved by using the herbicide glyphosate $\left(1560 \mathrm{~g}\right.$ a.i. $\left.\mathrm{ha}^{-1}\right)$. Since the experimental area has been frequently infested with large crabgrass (Digitaria sanguinalis), southern sandbur (Cenchrus echinatus) and alexandergrass (Brachiaria plantaginea), the herbicide oxadiazon (1000 $\mathrm{g}$ a.i. $\left.\mathrm{ha}^{-1}\right)$ was applied shortly after sowing. Remaining weeds not reached by herbicides were controlled manually with a hoe, including the no-till area.

Nitrogen sidedressing (different rates of $\mathrm{N}$ ) was performed at the beginning of the panicle differentiation stage (cottony stage) for each cultivar. When approximately $90 \%$ of the panicles had grains of typical mature coloration, manual harvest was carried out. Panicles were left to dry in the sun for one to two days on a concrete floor area, and later submitted to mechanical threshing in a research plot thresher.

The number of days elapsed between emergence and the time when $50 \%$ of the plants had flowered, and between emergence and when maturation was attained in $90 \%$ of the panicles of the plots, were also evaluated during the experimental period. Soil resistance to penetration was determined by the time plants were flowering with the use of an impact penetrometer. Plant height was evaluated when the grains were in the soft dough stage, in 10 plants at random, in the usable area of each plot, by measuring the mean distance between the soil surface and the upper extremity of the tallest panicle.

The degree of lodging was obtained from visual observations in the maturation stage, by using the following rating scale: 0 - no lodging; 1 - up to $5 \%$ of lodged plants; 2 - from 5 to $25 \%$; 3 - from 25 to $50 \%$; 4 - from 50 to $75 \%$, and 5 - from 75 to $100 \%$ of lodged plants. To determine the $\mathrm{N}$ content in the leaves, 25 "flag" leaves were collected from each plot, during the flowering period, then dried at $60^{\circ} \mathrm{C}$ in an oven and ground.

The number of panicles per square meter was obtained by counting the number of panicles in $1.0 \mathrm{~m}$ of plants in a row from the usable area of the plots. The number of grain-bearing spikelets was obtained by counting the number of spikelets bearing grain in 15 panicles after their separation by air flow. The mass of 100 grains was evaluated by collecting at random and weighing two samples of 100 grains from each plot (13\% wet basis). The productivity was calculated by weighing the unhulled grains collected from the usable area of the plots, correcting their moisture content to $13 \%$ and converting to $\mathrm{kg} \mathrm{ha}^{-1}$.

To obtain the milled rice yield, a $100 \mathrm{~g}$ sample of unhulled rice grains was collected from each plot, and processed in a test mill for 1 minute; then, the polished grains were weighed and the value found was considered as head rice yield, with the results expressed as percentages. Later, the polished grains were placed in the no. 2 trieur-type grader and grain separation was processed for 30 seconds; grains that remained in the trieur-type grader were weighed and the head rice yield was obtained, expressed as percentage.

Data obtained were submitted to analysis of variance using the $\mathrm{F}$ test. Cultivars and soil management means were compared by the Tukey test at $5 \%$, and a polynomial regression analysis was performed for nitrogen.

\section{RESULTS AND DISCUSSION}

No triple interaction effect (cultivar $\mathrm{x}$ soil tillage $\mathrm{x}$ nitrogen rates) was observed for any of the studied parameters. Plant emergence occurred uniformly on November 21 and December 1, therefore 5 and 7 days after sowing for the 1999/00 and 2000/01 cropping seasons, respectively. Full cultivar flowering after plant emergence, occurred from 65 to 70 days for cultivar Primavera, 84 to 94 days for Maravilha and 85 to 94 days for Confiança, considering the two cropping years. Plant harvesting was performed, on average at 94, 107 and 107 days after plant emergence in the 1999/00 cropping season, and at 95, 114 and 114 days in the 2000/ 01 cropping season, for cultivars Primavera, Maravilha and Confiança, respectively. 
The characteristic penetration resistance curves as a function of soil density and water content on a volume basis, have been standardized for water content at field capacity (Figure 1). In the 1999/00 cropping season, harrow tilling showed higher mechanical resistance value for the depth from 0.0-0.60 m, when compared with moldboard plow and no-till. A decrease in mechanical resistance to penetration can be observed at depths between $0.15 \mathrm{~m}$ and $0.45 \mathrm{~m}$. This means that the greatest mechanical resistance can be found in the 0.0$0.15 \mathrm{~m}$ layer. Stone \& Silveira (1999) and Silva et al. (2000) found an opposing behavior, i.e., they observed an increase in mechanical resistance in the profile, at the depths from 0.15 to $0.45 \mathrm{~m}$. Despite this behavior, the values of resistance to penetration herein observed are below the value considered as critical for rice root development, which is $2.0 \mathrm{MPa}$ (Taylor et al., 1966; Nesmith, 1987). Several values of soil mechanical resistance to penetration considered critical for root development can be found in the literature. However, 2.0 $\mathrm{MPa}$ has been accepted by most researchers as the critical limit (Silva et al., 2000).

In the 2000/01 cropping season, the shape of the mechanical resistance to penetration curve, considering the 0.0-0.60 m layer, was similar to that for the 1999/00

\section{9/2000 Cropping season}
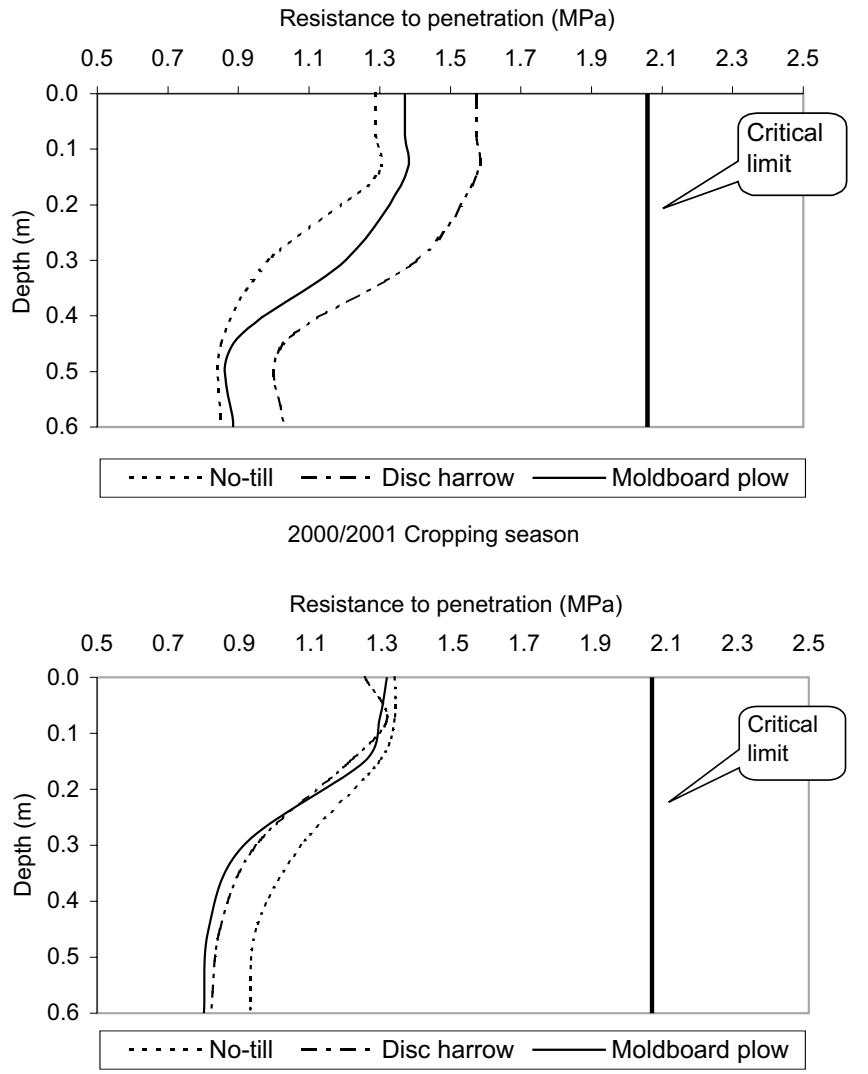

Figure 1 - Resistance to soil penetration down to a $0.60 \mathrm{~m}$ depth at the time of flowering in upland rice; 1999/00 and 2000/ 01 cropping seasons. cropping season. The amplitude of the curves decreased, and similarity occurred between harrow tilling and moldboard plow tilling. For no-till, the mechanical resistance behavior was better than for the other tillage systems, at the soil layer from $0.0-0.60 \mathrm{~m}$, for the second cropping season. The resistance to penetration values for the three tillage systems were below the critical limit (Figure 1).

For the cropping seasons under evaluation and taking into account the water management for the crop, where the soil is maintained at water contents near field capacity, no change in mechanical resistance to penetration that would jeopardize root development was observed. The three tillage systems presented similar behavior. For the $0.0-0.15 \mathrm{~m}$ depth, resistance is greater, decreasing until $0.45 \mathrm{~m}$, and showing constant behavior beyond this point. Because of the great spatial variability in soil resistance to penetration, results must be interpreted comparatively (Correchel et al., 1997).

With regard to plant height (Table 1), there was an effect of cultivars during the first year, and of cultivars and soil tillage during in the second cropping year. Cultivar Maravilha had the shortest plant height, followed by Confiança and Primavera, with the latter showing the highest values. Plant height is a parameter directly linked to genotype, when the same external factors are at play. Harrow tillage provided the shortest plant height, fol-

Table 1 - Mean values for plant height, lodging and $\mathrm{N}$ content in the leaves of upland rice cultivars under different soil management systems and rates of $\mathrm{N}$ as sidedressing.

\begin{tabular}{|c|c|c|c|c|c|c|}
\hline \multirow[t]{2}{*}{ Treatment } & \multicolumn{2}{|c|}{ Plant height } & \multicolumn{2}{|c|}{ Lodging } & \multicolumn{2}{|c|}{$\begin{array}{c}\mathrm{N} \text { content in } \\
\text { leaves }\end{array}$} \\
\hline & $99 / 00$ & $00 / 01$ & $99 / 00$ & $00 / 01$ & $99 / 00$ & $00 / 01$ \\
\hline & \multicolumn{2}{|c|}{$----c m--.-$} & \multicolumn{2}{|c|}{--- rating ${ }^{1}$--- } & \multicolumn{2}{|c|}{--- $\mathrm{g} \mathrm{kg}^{-1}$} \\
\hline \multicolumn{7}{|l|}{ Cultivar } \\
\hline Primavera & $124 \mathrm{a}$ & $117 \mathrm{a}$ & 1.16 & $0.71 \mathrm{a}$ & 32.9 & 39.6 \\
\hline Maravilha & $106 \mathrm{c}$ & $95 \mathrm{c}$ & 0.07 & $0.00 \mathrm{~b}$ & 29.8 & 31.8 \\
\hline Confiança & $111 \mathrm{~b}$ & $110 \mathrm{~b}$ & 0.04 & $0.00 \mathrm{~b}$ & 31.2 & 30.3 \\
\hline \multicolumn{7}{|l|}{ Soil Tillage } \\
\hline No-Till & 115 & $107 \mathrm{ab}$ & 0.49 & 0.17 & 31.9 & 34.3 \\
\hline Harrow & 113 & $106 \mathrm{~b}$ & 0.26 & 0.13 & 31.3 & 33.7 \\
\hline Moldboard & 113 & $109 \mathrm{a}$ & 0.33 & 0.32 & 30.7 & 33.7 \\
\hline \multicolumn{7}{|c|}{ Rates of $\mathrm{N}\left(\mathrm{kg} \mathrm{ha}^{-1}\right)$} \\
\hline 0 & 107 & 105 & 0.04 & 0.12 & 29.7 & 32.5 \\
\hline 25 & 113 & 107 & 0.11 & 0.21 & 31.0 & 33.1 \\
\hline 50 & 113 & 108 & 0.32 & 0.18 & 30.8 & 34.1 \\
\hline 75 & 116 & 108 & 0.51 & 0.24 & 31.3 & 34.7 \\
\hline 100 & 119 & 109 & 0.94 & 0.27 & 33.7 & 35.1 \\
\hline C.V. $(\%)$ & 6.13 & 4.72 & 31.92 & 34.55 & 7.76 & 6.47 \\
\hline
\end{tabular}

${ }^{1}$ The analysis refers to data transformed to square root of $x+0.5$ Means followed by a common letter, within each parameter (cultivars and soil management) are not different by Tukey test $(P=0.05)$ 
lowed by no-till and moldboard plow, however with a difference considered small between the different soil management systems. No effect of nitrogen rates on plant height was observed for the two cropping years. It was expected that, as the $\mathrm{N}$ rates increased, greater plant development would occur, and intensify the degree of lodging. Data obtained are in agreement with Crusciol (1998) who, while studying the effects of irrigation water depths and two nutrient levels on the behavior of cultivars IAC 201 and Carajás, found that the nutrient rates did not affect plant development. On the other hand, it disagrees with Diniz (1975), Campello Jr. (1985) and Arf (1993) who consider nitrogen the nutrient which most affects plant height, causing lodging.

There was an effect of cultivars with regard to plant lodging for the two cropping years and of the interaction cultivar $\mathrm{x}$ rate of $\mathrm{N}$ for the first cropping year; the partitioning of significant interactions in the analysis of variance is shown in Table 2. Cultivars Maravilha and Confiança presented low lodging values (rate 1, i.e.,

Table 2 - Partitioning of the significant interaction of the analysis of variance for rice cultivars and rates of $\mathrm{N}$ with regard to plant lodging ${ }^{1} ; 1999 / 00$ cropping season.

\begin{tabular}{lccccc}
\hline \multirow{2}{*}{ Cultivar } & \multicolumn{5}{c}{ Rate of N } \\
\cline { 2 - 6 } & 0 & 25 & 50 & 75 & 100 \\
\hline & $-1 .-13 \mathrm{aC}$ & $0.31 \mathrm{aC}$ & $1.07 \mathrm{aB}$ & $1.33 \mathrm{aB}$ & $4.11 \mathrm{aA}$ \\
Primavera & $0.13 \mathrm{aA}$ & $0.06 \mathrm{bA}$ \\
Maravilha & $0.00 \mathrm{aA}$ & $0.06 \mathrm{aA}$ & $0.06 \mathrm{bA}$ & $1.18 \mathrm{bA}$ & $0.00 \mathrm{bA}$ \\
Confiança & $0.00 \mathrm{aA}$ & $0.00 \mathrm{aA}$ & $0.00 \mathrm{bA}$ & $0.21 \mathrm{bA}$ & $0.00 \mathrm{bA}$ \\
\hline L.S.D. & \multicolumn{4}{c}{ cultivar within rate $=0.28$} \\
\hline
\end{tabular}

${ }^{1}$ Rating scale: $\mathrm{O}$ - no lodging; 1 - up to $5 \%$ of lodged plants; 2 from 5 to $25 \% ; 3$ - from 25 to $50 \% ; 4$ - from 50 to $75 \%$; and 5 from 75 to $100 \%$ of lodged plants.

Means followed by a common letter in the column do not differ by the Tukey test at $5 \%$. up to $5 \%$ of lodged plants). In turn, cultivar Primavera showed a high plant lodging index only in the $100 \mathrm{~kg}$ $\mathrm{ha}^{-1} \mathrm{~N}$ as sidedressing treatment, reaching rate 4 , i.e., from 50 to $75 \%$ of lodged plants. For this cultivar, the increase in nitrogen rate intensified the degree of plant lodging. This could be explained by a characteristic of the cultivar, which consists of "intermediate-type" plants, with greater vegetative development related to the increase in supplied nitrogen, since plant heights were $116,124,125,126$ and $129 \mathrm{~cm}$ at rates of $\mathrm{N}$ starting from zero, 25, 50, 75 and $100 \mathrm{~kg} \mathrm{ha}^{-1}$. Cultivars Maravilha and Confiança, however, are "modern-type" plants, for which high $\mathrm{N}$ rates can be utilized without causing lodging problems.

There was an effect of cultivars and of the cultivar $\mathrm{x}$ rate interaction in relation to $\mathrm{N}$ content in the leaves (Table 1). Cultivar Primavera had greater leaf $\mathrm{N}$ contents relative to Maravilha and Confiança. They, however, fall within the range that is adequate for the crop, i.e., 27-35 $\mathrm{g} \mathrm{kg}^{-1}$ (Raij et al., 1996). In regard to rates of $\mathrm{N}$ (Table 3 ), there was an increase in foliar $\mathrm{N}$ content with the increase in nitrogen fertilization for the cultivars Primavera and Maravilha for the first cropping season. On the other hand, data did not adjust a linear or quadratic equation, maybe because of the small increment observed in foliar nutrient content as a consequence of the nitrogen sidedressing application. With respect to partitioning of $\mathrm{N}$ rates within cultivars, Primavera always showed higher $\mathrm{N}$ contents in the leaves for all rates of $\mathrm{N}$ (Table 3 ) during the two cropping years. Also, with regard to partitioning of $\mathrm{N}$ rates within cultivars, there was an increase in $\mathrm{N}$ content in the leaves with the increase in the rates of $\mathrm{N}$, except for cultivar Confiança during the second cropping season. In this case, the content found in the control was already within the adequate range. Soil tillage, however, did not interfere with foliar $\mathrm{N}$ content in both years of experimentation.

Table 3 - Partitioning of significant interactions in the analysis of variance for rice cultivars and rates of $\mathrm{N}$ with regard to the content of $\mathrm{N}$ in the leaves. $\mathrm{C}$

\begin{tabular}{|c|c|c|c|c|c|}
\hline & \multicolumn{5}{|c|}{ Rate of $\mathrm{N}$} \\
\hline & 0 & 25 & 50 & 75 & 100 \\
\hline & \multirow{2}{*}{\multicolumn{5}{|c|}{ $1999 / 00$}} \\
\hline & & & \multicolumn{3}{|c|}{$\begin{array}{rr}1999 / 00\end{array}$} \\
\hline Pimavera & $29.4 \mathrm{aC}$ & $31.5 \mathrm{abBC}$ & $33.1 \mathrm{aB}$ & $33.5 \mathrm{aB}$ & $36.8 \mathrm{aA}$ \\
\hline Maravilha & $28.7 \mathrm{aB}$ & $29.3 \mathrm{abB}$ & $28.9 \mathrm{bAB}$ & $30.0 \mathrm{bAB}$ & $32.1 \mathrm{bA}$ \\
\hline \multirow[t]{2}{*}{ Confiança } & $31.0 \mathrm{aA}$ & $32.1 \mathrm{aA}$ & $30.4 \mathrm{bA}$ & $30.3 \mathrm{bA}$ & $32.2 \mathrm{bA}$ \\
\hline & \multicolumn{5}{|c|}{$2000 / 01$} \\
\hline Primavera & $37.0 \mathrm{aB}$ & $37.6 \mathrm{aB}$ & $40.3 \mathrm{aA}$ & $41.4 \mathrm{aA}$ & $41.6 \mathrm{aA}$ \\
\hline Maravilha & $28.8 \mathrm{cB}$ & $28.9 \mathrm{cB}$ & $30.4 \mathrm{bAB}$ & $31.1 \mathrm{bAB}$ & $32.5 \mathrm{bA}$ \\
\hline Confiança & $31.7 \mathrm{bA}$ & $32.9 \mathrm{bA}$ & $31.7 \mathrm{bA}$ & $31.6 \mathrm{bA}$ & $31.2 \mathrm{bA}$ \\
\hline L.S.D. & \multicolumn{5}{|c|}{$\begin{array}{l}\text { Cultivar within rate of } \mathrm{N}=2.73(1999 / 00) \text { and } 2.12(2000 / 01) \\
\text { Rates of } N \text { within cultivar }=3.28(1999 / 00) \text { and } 2.47(2000 / 01)\end{array}$} \\
\hline
\end{tabular}

Means followed by the same lower case letter, in the column, and upper case letter, in the row, are not different by the Tukey test at $5 \%$. 
Table 4 - Mean values for the number of panicles $\mathrm{m}^{-2}$, number of grain-bearing spikelets per panicle and mass of 100 grains in upland rice cultivars relative to soil tillage systems and different rates of $\mathrm{N}$ as sidedressing.

\begin{tabular}{|c|c|c|c|c|c|c|}
\hline \multirow{2}{*}{ Treatment } & \multicolumn{2}{|c|}{ No. panicles $\mathrm{m}^{-2}$} & \multicolumn{2}{|c|}{ No. grain-bearing spikelets } & \multicolumn{2}{|c|}{ Mass of 100 grains } \\
\hline & $99 / 00$ & $00 / 01$ & $99 / 00$ & $00 / 01$ & $99 / 00$ & $00 / 01$ \\
\hline & & & & & $-\cdots$ & $-\cdots---$. \\
\hline \multicolumn{7}{|l|}{ Cultivar } \\
\hline Primavera & $225 \mathrm{~b}$ & $203 \mathrm{~b}$ & $138 \mathrm{a}$ & 162 & $2.72 \mathrm{a}$ & $2.61 \mathrm{a}$ \\
\hline Maravilha & $287 \mathrm{a}$ & $271 \mathrm{a}$ & $124 \mathrm{~b}$ & 105 & $2.64 \mathrm{~b}$ & $2.19 \mathrm{c}$ \\
\hline Confiança & $236 \mathrm{~b}$ & $215 b$ & $103 \mathrm{c}$ & 133 & $2.62 \mathrm{~b}$ & $2.41 \mathrm{~b}$ \\
\hline \multicolumn{7}{|l|}{ Soil Tillage } \\
\hline No-Till & 251 & $244 \mathrm{a}$ & 125 & 129 & 2.67 & 2.42 \\
\hline Harrow & 244 & $221 \mathrm{~b}$ & 120 & 134 & 2.66 & 2.38 \\
\hline Moldboard & 253 & $225 \mathrm{~b}$ & 119 & 137 & 2.66 & 2.41 \\
\hline \multicolumn{7}{|c|}{ Rates of $\mathrm{N}\left(\mathrm{kg} \mathrm{ha}^{-1}\right)$} \\
\hline 0 & 239 & 224 & 112 & 128 & 2.77 & 2.44 \\
\hline 25 & 251 & 236 & 121 & 135 & 2.69 & 2.41 \\
\hline 50 & 258 & 235 & 121 & 136 & 2.64 & 2.39 \\
\hline 75 & 245 & 228 & 124 & 135 & 2.63 & 2.40 \\
\hline 100 & 253 & 228 & 129 & 133 & 2.58 & 2.38 \\
\hline C.V. (\%) & 15.38 & 17.56 & 14.54 & 14.95 & 3.26 & 4.16 \\
\hline
\end{tabular}

ns - non significant

*and **significant at the 5 and $1 \%$ level, respectively, by $\mathrm{F}$ test

Means followed by a common letter, within each parameter (cultivars and soil management) are not different by the Tukey test at $5 \%$.

Differences were observed between the number of panicles per $\mathrm{m}^{2}$ in the cultivars during both cropping years (Table 4), since Maravilha had larger values in comparison to cultivars Primavera and Confiança, which in turn did not present differences among themselves. During the second year (2000/01), soil tillage also had an effect, notill yielding higher values than those obtained for harrow tillage and moldboard plow, which did not show differences between themselves. The rates of $\mathrm{N}$ did not influence the number of panicles per $\mathrm{m}^{2}$, demonstrating that nitrogen has no effect in transforming vegetative buds into reproductive, since application was performed after tillering, more precisely at the floral differentiation stage.

From the mean values obtained in the evaluation of the number of grain-bearing spikelets per panicle (Table 4) there were differences for cultivars and for the cultivar x soil tillage interaction, for the 2000/01 cropping season. Cultivar Primavera had the largest number of grain-bearing spikelets during both cropping years. The partitioning of significant interactions in the analysis of variance for the number of grain-bearing spikelets is shown in Table 5. Primavera had the largest number of grain-bearing spikelets for the different soil tillage systems. With regard to soil tillage within cultivars, there were differences only for the cultivar Primavera, the notill treatment showed a smaller number of grain-bearing spikelets per panicle.

Despite the difference between cultivars regarding the mass of 100 grains, the difference is rather small (Table 4) and all three cultivars had long and thin type
Table 5 - Partitioning of the significant interaction in the analysis of variance for rice cultivars and soil tillage relative to the number of grain-bearing spikelets; 2000/01 cropping season.

\begin{tabular}{lccc}
\hline \multirow{2}{*}{ Cultivar } & \multicolumn{3}{c}{ Soil Tillage } \\
\cline { 2 - 4 } & No-till & Harrow & Moldboard \\
\hline Primavera & $146 \mathrm{aB}$ & $171 \mathrm{aA}$ & $170 \mathrm{aA}$ \\
Maravilha & $109 \mathrm{bA}$ & $103 \mathrm{cA}$ & $102 \mathrm{cA}$ \\
Confiança & $133 \mathrm{aA}$ & $128 \mathrm{bA}$ & $138 \mathrm{bA}$ \\
\hline \multirow{4}{*}{ L.S.D. } & Cultivar within soil tillage $=18.68$ \\
& Soil tillage within cultivar $=18.68$ \\
\hline
\end{tabular}

Means followed by the same lower case letter, in the column, and upper case letter, in the row, are not different by the Tukey test at $5 \%$.

grains. Among cultivars, grain productivity was prominent for Primavera during both cropping seasons, and in the first year Maravilha had productivity similar to Primavera (Table 6). In the second year, however, Maravilha had productivity similar to Confiança. No difference in productivity was detected with the application of different nitrogen rates. However, the $\mathrm{N}$ contents found in the leaves are within the adequate range for the crop $\left(27-35 \mathrm{~g} \mathrm{~kg}^{-1}\right)$. The lack of response to nitrogen can be, probably, attributed to the nitrogen supplied by the soil, since the area was cropped with beans before being planted with millet; beans, among other characteristics, can fix nitrogen from atmospheric air. The results obtained agree with those of Arf et al. (1996), who studied the cultivars Rio Paranaíba, Guarani and Araguaia sub- 
Table 6 - Mean values for grain productivity, milled and head rice yields in upland rice cultivars relative to soil tillage systems and different rates of $\mathrm{N}$ as sidedressing.

\begin{tabular}{|c|c|c|c|c|c|c|}
\hline \multirow{2}{*}{ Treatment } & \multicolumn{2}{|c|}{ Grain productivity } & \multicolumn{2}{|c|}{ Milled rice yield } & \multicolumn{2}{|c|}{ Head rice yield } \\
\hline & $99 / 00$ & $00 / 01$ & $99 / 00$ & $00 / 01$ & $99 / 00$ & $00 / 01$ \\
\hline & \multicolumn{2}{|c|}{ - $\mathrm{kg} \mathrm{ha}^{-1} \ldots$} & \multicolumn{4}{|c|}{ - } \\
\hline \multicolumn{7}{|l|}{ Cultivar } \\
\hline Primavera & $3.905 \mathrm{a}$ & $4.179 \mathrm{a}$ & $70.3 \mathrm{~b}$ & $72.2 \mathrm{~b}$ & $55.5 \mathrm{~b}$ & 56.2 \\
\hline Maravilha & $4.023 \mathrm{a}$ & $3.256 \mathrm{~b}$ & $67.4 \mathrm{c}$ & $71.5 \mathrm{c}$ & $50.1 \mathrm{c}$ & 54.4 \\
\hline Confiança & $3.421 \mathrm{~b}$ & $3.023 \mathrm{~b}$ & $71.3 \mathrm{a}$ & $73.4 \mathrm{a}$ & $58.6 \mathrm{a}$ & 61.1 \\
\hline \multicolumn{7}{|l|}{ Soil Tillage } \\
\hline No-till & 3.857 & $3.748 \mathrm{a}$ & 69.5 & $72.0 \mathrm{~b}$ & 54.1 & 55.3 \\
\hline Harrow & 3.816 & $3.088 \mathrm{~b}$ & 70.0 & $72.6 \mathrm{a}$ & 54.9 & 57.9 \\
\hline Moldboard & 3.676 & $3.623 \mathrm{a}$ & 69.6 & $72.5 \mathrm{ab}$ & 55.1 & 58.5 \\
\hline \multicolumn{7}{|c|}{ Rates of $\mathrm{N}\left(\mathrm{kg} \mathrm{ha}^{-1}\right)$} \\
\hline 0 & 3.592 & 3.358 & 70.0 & 71.8 & 56.7 & 57.0 \\
\hline 25 & 3.898 & 3.556 & 69.9 & 72.2 & 55.5 & 57.3 \\
\hline 50 & 3.763 & 3.573 & 69.5 & 72.5 & 53.6 & 57.3 \\
\hline 75 & 3.854 & 3.555 & 69.3 & 72.6 & 54.2 & 57.2 \\
\hline 100 & 3.808 & 3.390 & 69.7 & 72.8 & 53.7 & 57.3 \\
\hline C.V. $(\%)$ & 18.53 & 21.59 & 2.38 & 1.49 & 8.81 & 5.42 \\
\hline
\end{tabular}

n.s. - non significant; **significant at the $1 \%$ level by $\mathrm{F}$ test

Means followed by a common letter, within each parameter (cultivars and soil management) are not different by the Tukey test at $5 \%$.

Table 7 - Partitioning of the significant interaction in the analysis of variance for rice cultivars and soil tillage relative to head rice yield (\%). 2000/01 cropping season.

\begin{tabular}{lccc}
\hline \multirow{2}{*}{ Cultivar } & \multicolumn{3}{c}{ Soil Tillage } \\
\cline { 2 - 4 } & No-till & Harrow & Moldboard \\
\hline Primavera & $56.0 \mathrm{bA}$ & $55.6 \mathrm{bA}$ & $56.9 \mathrm{bA}$ \\
Maravilha & $50.7 \mathrm{cB}$ & $56.4 \mathrm{bA}$ & $56.0 \mathrm{bA}$ \\
Confiança & $59.1 \mathrm{aB}$ & $61.7 \mathrm{aA}$ & $62.5 \mathrm{aA}$ \\
\hline \multirow{2}{*}{ L.S.D. } & Cultivar within soil tillage $=2.91$ \\
& Soil tillage within cultivar $=$ & 2.91 \\
\hline
\end{tabular}

Means followed by the same lower case letter, in the column, and upper case letter, in the row, are not different by the Tukey test at $5 \%$.

mitted to different nitrogen rates as sidedressing $(0,30$, 60 and $90 \mathrm{~kg} \mathrm{ha}^{-1}$ ), and found that nitrogen fertilization did not influence agronomic characteristics and grain productivity. Data are also in agreement with Crusciol (1998), who verified that nutrient rates did not affect plant development and the remaining assessed parameters. Data of Arf et al. (1996) and Crusciol (1998) were also obtained in Selvíria (MS), therefore under similar climate and soil conditions. On the other hand, Stone et al. (1979) obtained productivity increments by applying up to $60 \mathrm{~kg} \mathrm{ha}^{-1} \mathrm{~N}$, and Stone et al. (1999) observed that the maximum economic rate of nitrogen for upland rice, sown at $0.20 \mathrm{~m}$ spacing between rows is $87.3 \mathrm{~kg} \mathrm{ha}^{-1}$. Again, with regard to grain productivity relative to soil tillage, it can be observed that the highest values were obtained with no-till and with moldboard plow for the second cropping season (2000/01); for the first year no difference was observed among treatments.

Cultivar Confiança standed at topy, since it showed higher milled and head rice yields, followed by Primavera (Table 6). Cultivar Maravilha presented the lowest values for the two assessed characteristics. For the second cropping season there were also effects of soil tillage and of cultivar $\mathrm{x}$ soil tillage interaction with respect to head rice yield (partitioning shown in Table 7). Cultivar Confiança showed the highest values for head rice yield, both in no-till and in the soil tillage systems that used disk harrow or moldboard plow. With regard to soil tillage within cultivars, effects were detected for cultivars Maravilha and Confiança only, the tilled soil with harrow and moldboard plow having higher head rice yield. The different nitrogen rates as sidedressing did not cause alterations in milled and head rice yields for both cropping seasons. Results are in agreement with those of by Arf et al. (1996), who did not detect nitrogen fertilization effects on the milled and head rice yields in a study also carried out in Selvíria (MS).

\section{CONCLUSIONS}

Cultivars Primavera and Maravilha showed higher grain productivity relative to Confiança but the latter had higher milled and head rice yields after processing. Soil tillage with moldboard plow and no-till posi- 
tively affected rice agronomic and production characteristics. For milled rice yield of sprinkler-irrigated upland rice, however, tillage with harrow and moldboard plow showed better results relative to no-till. Nitrogen sidedressing did not interfere with agronomic and production characteristics, as well as with the milled rice yield for the sprinkler-irrigated rice cultivars Primavera, Maravilha and Confiança.

\section{ACKNOWLEDGEMENT}

To FAPESP for the financial support and for two scholarships granted during the period of this research project.

\section{REFERENCES}

AQUINO, A.R.L. Níveis de modos de aplicação de uréia ${ }^{15} \mathrm{~N}$ no arroz (Oryza sativa $\mathrm{L}$.) submetidos a veranicos. Piracicaba: USP/ESALQ, 1984. 134p. (Tese - Doutorado)

ARF, O. Efeitos de densidades populacionais e adubação nitrogenada sobre o comportamento de cultivares de arroz irrigado por aspersão. Ilha Solteira: UNESP/FEIS, 1993. 63p. (Tese - Livre-Docência)

ARF, O.; SÁ, M.E.; RODRIGUES, R.A.F.; BUZETTI, S.; STRADIOTO, M.F.; PASTANA, A.R.M.P. Comportamento de cultivares de arroz para condição de sequeiro irrigados por aspersão em diferentes doses de adubação nitrogenada em cobertura. Científica, v.24, p.85-97, 1996.

ARF, O.; RODRIGUES, R.A.F.; SÁ, M.E.; CRUSCIOL, C.A.C. Influência da época de semeadura no comportamento de cultivares de arroz irrigado por aspersão em Selvíria, MS. Pesquisa Agropecuária Brasileira, v.35, p.1967-1976, 2000.

CAMPELLO JR., J.O. Avaliação da capacidade de extração de água do solo pelo arroz de sequeiro (Oryza sativa $\mathrm{L}$.) sob diferentes doses de nitrogênio. Piracicaba: USP/ESALQ, 1985. 127p. (Tese - Doutorado)

CORRECHEL, V.; SILVA, A.P.; TORMENA, C.A.; SANCHES, A.C. Resistência de um Latossolo Roxo ao penetrômetro em dois sistemas de preparo do solo (Compact disc). In: CONGRESSO BRASILEIRO DE CIÊNCIA DO SOLO, 26., Rio Janeiro, 1997. Resumos. Rio de Janeiro: SBCS, 1997.

CRUSCIOL, C.A.C. Efeitos de lâminas de água e da adubação mineral em dois cultivares de arroz de sequeiro sob irrigação por aspersão. Botucatu: UNESP/FCA, 1998. 129p. (Tese - Doutorado)

DINIZ, J.A. Comportamento de cultivares de arroz, em terras altas, sob regime de irrigação por aspersão em diferentes níveis de adubação nitrogenada. Viçosa: UFV, 1975. 53p. (Dissertação - M.S.)
DINIZ, J.A.; BRANDÃO, S.S.; GIUDICE, R.M.; SEDIYAMA, C.S.; LOUREIRO, B.T. Comportamento de variedades de arroz, em terras altas, sob regime de irrigação por aspersão em diferentes níveis de adubação nitrogenada. Experientiae, v.22, p.235-262, 1976.

DOORENBOS, J.; PRUITT, W.O. Las necessidades de agua de los cultivos. Roma: FAO, 1976. 194p. (Estudos FAO: Riego e Drenage, 24).

FORNASIERI FILHO, D.; FORNASIERI, J.L. Manual da cultura do arroz. Jaboticabal: FUNEP, 1993. 221p.

GROHMANN, F. Distribuição e tamanho de poros em três tipos de solos do Estado de São Paulo. Bragantia, v.21, p.285-295, 1960.

NESMITH, D.S. Soil compaction in double cropped wheat and soybean on Ultisol. Soil Science Society of America Journal, v.51, p.183-186, 1987.

RAIJ, B. van; QUAGGIO, J.A. Métodos de análise de solo para fins de fertilidade. Campinas: Instituto Agronômico, 1983. 31p. (Boletim Técnico, 81).

RAIJ, B. van; CANTARELLA, H.; QUAGGIO, J.A.; FURLANI, A.M.C. Recomendações de adubação e calagem para o estado de São Paulo. 2.ed. Campinas: Instituto Agronômico, 1996. 285p. (Boletim, 100).

RICHARDS, L.A. Pressure membrane apparatus construction and use. Agricultural Engineer, v.28, p.451-454, 1947.

RICHARDS, L.A.; FIREMAN, M. Pressure-plate apparatus for measuring moisture sortin and transmission by soils. Soil Science, v.56, p.395404, 1943.

SILVA, V.R.; REINERT, D.J.; REICHERT, J.M. Resistência mecânica do solo à penetração influenciada pelo tráfego de uma colhedora em dois sistemas de manejo do solo. Ciência Rural, v.30, p.795-801, 2000.

STONE, L.F.; PEREIRA, A.L. Sucessão arroz-feijão irrigado por aspersão: efeito de espaçamento entrelinhas, adubação e cultivar no crescimento, desenvolvimento radicular e consumo d'água do arroz. Pesquisa Agropecuária Brasileira, v.29, p.1577-1592, 1994.

STONE, L.F.; SILVEIRA, P.M. Efeitos do sistema de preparo na compactação do solo, disponibilidade hídrica e comportamentos do feijoeiro. Pesquisa Agropecuária Brasileira, v.34, p.83-91, 1999.

STONE, L.F.; OLIVEIRA, A.B.; STEINMETZ, S. Deficiência hídrica e resposta de cultivares de arroz de sequeiro ao nitrogênio. Pesquisa Agropecuária Brasileira, v.14, p.295-301, 1979.

STONE, L.F.; SILVEIRA, P. M.; MOREIRA, J. A. A.; YOKOYAMA, L.P. Adubação nitrogenada em arroz sob irrigação suplementar por aspersão. Pesquisa Agropecuária Brasileira, v.34, p.927-932, 1999.

TAYLOR, H.M.; ROBERTSON, G.M.; PARKER, J.J. Soil strength root penetration relations for medium to coarse textured soil materials. Soil Science, v.102, p.18-22, 1966

$\overline{\text { Received April 16, }} 2002$ 